$\square$ 諸金属(フニロニッケル)

\section{5. 結言}

近年, 需要の飛躍的増大は期待できず, エネルギー価格が高騰 する中でフェロニッケル産業の共通の課題は, 徹底した省力と省
エネルギーによるコストの引き下げであろう。当社は直労 1 人当 り年間 2 億円の売上げを目標としている。また当社の水力自家発 電を有効に生かすとともに，石炭利用により総コストの引き下げ に努力している。

Ferro-Nickel Smelting at Toyama Showa Denko Co., Ltd.

by Humihiko KUSAMA, Takuya TAMOH and Shunsuke NAGASAKI

Toyama Showa Denko Co., Ltd. (TSK) is situated in the industrial area near by the Toyama port. TSK is smelting ferro-alloys such as ferro-nickel, ferro-chromium and ferro-molybdenum, and these products are mainly used for stainless steel making.

TSK had been Toyama works of Showa Denko Co., Ltd., but became the subsidiary of Showa Denko Co., Ltd. on January 22, 1979.

Since we started ferro-nickel smelting in 1969, we have had much experience about it during more than ten years.

At present, we go on smelting ferro-nickel, based on the rotary kiln-electric furnace process. The annual capacity of this process is about 4500 tons of nickel.

TSK is dependent for its raw material ores on garnierite obtained from the nickel oxide deposits in areas such as New Caledonia and Indonesia. Garnierite is a rich siliceous ore of which the nickel content varies between $2.3 \sim 2.6 \%$. Our process is to calcine these ores in the rotary kiln and to reduce the hot materials in the electric furnace. In this paper, the outline of our smelting process, and improvements of plants are described.

\title{
[3-14] 大江山ニッケル(株)のフェロニッケル製鍊
}

新 居 治 男 ${ }^{1}$

\section{1. 緒言}

当社は昭和 50 年 12 月, 日本治金工業(株)より分離し, 社名を 大江山ニッヶル (株) としたものであり, 営業内容はそれまでの大 江山製造所と変りなく, 業界にあつて独自の製鍊方法であるロー タリーキルンのみによるフェロニッケル粒鉄（ルッペ）の製造を 続けている。

製品のほとんどは日本治金工業 (株)川崎製造所においてステン レス製鋼のNi 源として使用され, 粒状で低炭素, 低シリコンであ るところから AOD プロセスの泠材としても高く評価されている。 一般ユーザ向けとしては原料, 然料を精選し, 硫黄含有量を抑 えたものを生産している。

前回の報告以降, 設備の合理化, 省エネルギー, 生産効率の向 上に努めて, 収率を向上させ, 原価低減をはかつてきた。従業員 数もピーク時の約半分の 270 名であり， $850 \sim 900 \mathrm{t} /$ 月の = ケルを生産している。最近のエネルギー情勢に対しては石炭燃焼 転换計画を進めている。

\section{2. 最近 10 年間の操業推移}

\section{$2 \cdot 1$ 推 移}

昭和 45 年以降の経過と生産量の推移を第 1 表に示す。

昭和 45 年に研究所を新築し, 基礎研究設備を充実し, 操業研究, 低品位鉱処理研究の体勢を整えた。同年, 原料処理設備を半乾式 より全湿式に改造して工程を単純化し, さらに, 配合, 粒度, 調 合の管理を改善し, Ni 収率の向上をはかつた。

一方, 環境対策については, 風光明媚な日本三景天の橋立を控 えており, 昭和 46 年, 排煙については電気集痤機, 排水について はシックナ 3 基を主とした排水処理設備を完備し, 大気污染防止, 1. 大江山ニッヶル株式会社取締役製造部長

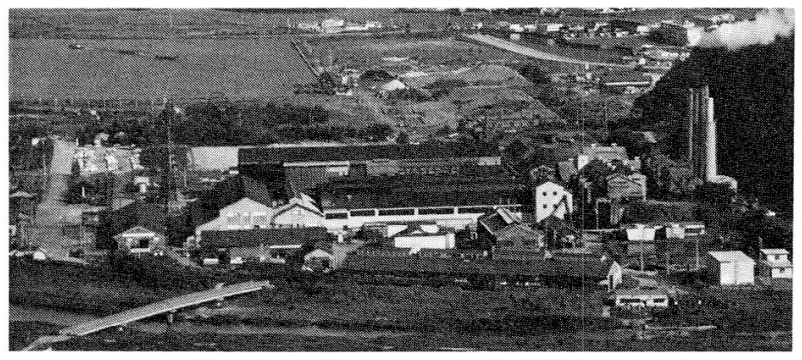

第 1 図大江山ニッケル製鍊所全景

第 1 表 最近 10 年間の推移（生産量は $\mathrm{Ni}$ 純分 $\mathrm{t} /$ 年)

\begin{tabular}{|c|c|c|}
\hline 年度 & 主 要 事 項 & 生産量 \\
\hline 45 & 原料処理を全湿式に改造, 研究所新築 & 8,540 \\
\hline 46 & 排煙, 排水処理設備設置 & 9,500 \\
\hline 47 & ラテライト鉱石製鍊パイロ.ットプラント設置 & 9,970 \\
\hline 48 & & 10,300 \\
\hline 49 & & 10,190 \\
\hline 50 & 日本治金工業 (株)より分離 & 8,280 \\
\hline 51 & 重油燃焼設備改善 & 10,100 \\
\hline 52 & 省エネルギープロジェクト完成 & 8,490 \\
\hline 53 & 選別工程合理化着手, 操帄法改善 & 9,470 \\
\hline 54 & 炬体放熱回収設備設置 & 9,910 \\
\hline
\end{tabular}

水質污濁防止に努め, 現在に至つている。現状の排出物の濃度等 は下記の通りである。

排煙 パイジン $<60 \mathrm{mg} / \mathrm{Nm}^{3}$, SOx $<10 \mathrm{ppm}, \mathrm{NOx}<20 \mathrm{ppm}$ 排水 $\mathrm{SS}<20 \mathrm{ppm}$

生産量は原料処理改善により大幅に増大し, 月産約 $1,000 \mathrm{t}$ ベ ースとなつた。

昭和51年にはェネルギー費用低減のために重油燃焼設備を改善 し, 高粘度重油の使用を可能とし, 昭和 52 年には予熱グレートの 熱効率の改善を始めとする省ェネルギープロジェクトを推進し， 
大幅な原価の低減に成功した。昭和53年から生産効率のみなおし を行ない, キルン装入量の最適化を始めとするエネルギー使用法 の改善と選別工程の合理化により $\mathrm{Ni}$ 収率の向上, 製品品質の改善 及び省力を目標とする計画を推進中であるが，その成果は確実に あらわれている。

\section{$2 \cdot 2$ 省エネルギープロジェクトの紹介}

昭和 52 年に製造工程における熱エネルギー収支を根本的にみな おし，熱エネルギーの約 $20 \%$ 節减に成功した。きわめて現場的で あるが,ここに簡単に紹介する。

$$
\begin{gathered}
\text { 目標(1)ケーク水分の低下 } 5 \% \text { （実績 } 5 \% \text { ） } \\
\text { (2)グレート熱効率の向上 } 10 \% \quad \text { （実績 } \quad 9 \% \text { ） }
\end{gathered}
$$

\section{具体的内容}

（イ）湿式分離粉砕原鉱石の過粉砕を防止するために鉱石 を水洗し微粒を分離しながら粗粒を目標粒度まで粉劯するようチ ニーブミルの使用方法を改善した。その結果, 原料の表面積が減 少し,ケーク水分の低下となつた。

（口） スラリーの予備脱水 スラリーの脱水のために凝集肪 を添加している。改善までは添加はドラムフィルタの夜槽の入口 で実施していたが, 多量の希釈水が給鉱され脱水効率が悪いので, スラリーの凝集をドラムフィルタ前段で行ない，上澄液を取り除 くために予備脱水槽を設置し洰過効率を向上させた。

（ソ）成型作業方法の改善 グレートに装入される原料の成 型率の向上による熱交換の改善をはかるため, フィーダー成型機 $\rightarrow$ グレートの層厚のコントロールシステムを確立し，成型率を60 \%から90\%に向上させた。

(二) キルンで発生する戻り原料の防止 キルンと予熱グレ ートの摺動部のシーリング方法を改良し, 炉内原料の一部溢流を ほぼ完全に防止した。

(木) 漏入空気の減少対策予熱グレートのあらゆる部分の エアロックを実施して, 効率の向上をはかつた。

等々の対策の実施により得られた成果はエネルギー原単位の低 下として, 重油 $30 \%$, 炭材 $10 \%$, 電力 $10 \%$ があるが，それに附随して炉材など材料費の低減にもみるべきも のがあつた。

\section{3. 現在の操業方法}

\section{$3 \cdot 1$ フローシート}

第 2 図に概略のフローシートを示す。また, 第 2 表に主要設備 の仕様を示す。原料は全て湿式で処理されてキルンに装入され， 半溶融状態での還元製鍊が行なわれ，選別工程においてメタルと スラグに分離し，製品ルッペを回収している。したがつて，国内 他社のエルケル法に比べ, 溶解用の電力エネルギーがない点が特 徵である。

\section{$3 \cdot 2$ 原料}

鉱石は輸入酸化鉱 (ガーニエライト) である。組成を第 3 表に 示す。

無煙炭は主として中国産で，コークスも一部配合している。組 成例を第 4 表に示す。

溶剤として石灰石を使用している。重油は製品に応じて A，ま たは C 重油を使用している。

\section{$3 \cdot 3$ 原料処理}

原料の粉碎は「分離粉砕」と称している独自の湿式ミル法で行 なう。原鉱石は多くの粘土分を含み, 粉碎の必要のないものが約 $50 \%$ \%, これが過粉砕されると脱水不良, 飛散ダストの増加に つながるので, 過粉碎を防止する方式を採用している。これによ つて含水率の高いリオチュバ鉱も使用可能となつている。

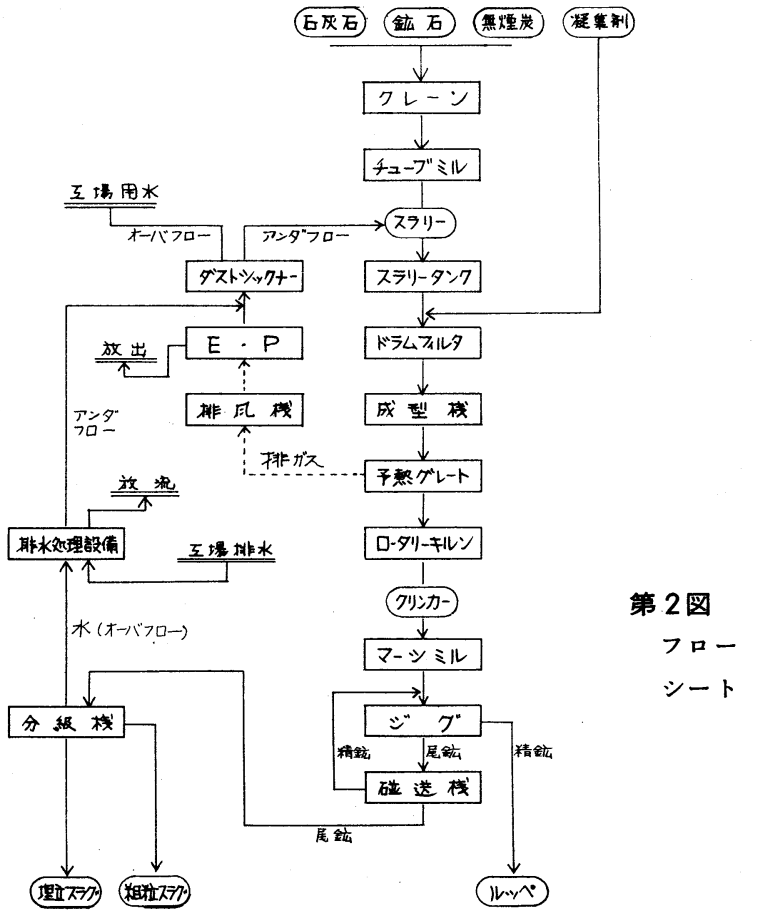

\begin{tabular}{|c|c|c|c|c|c|}
\hline 設 & 備 & 基数 & 能 & 力 & 法 \\
\hline 1 & 艀 & 32 隻 & 130 & Wet-t/隻 & \multirow[b]{2}{*}{$2.2 \mathrm{~m} \phi \times 8 \mathrm{~m}$} \\
\hline 2 & チ=ーブミル & 4基 & 65 & Dry $-t / h$ & \\
\hline 3 & スラリータンク & $12 " \prime$ & 325 & $\mathrm{~m}^{3}$ /基 & $6 \mathrm{~m} \phi$ \\
\hline 4 & ドラムフィルタ & $8 \prime \prime$ & 18 & Wet-t/h-基 & 洰布面積 70m² \\
\hline 5 & 成 型 機 & $4 \prime \prime$ & 50 & Dry- $\mathrm{t} / \mathrm{h} \cdot$ 基 & 口ール径 $1 \mathrm{~m} \phi \times 4 \mathrm{~m}$ \\
\hline 6 & 予熱グレート & $4 \prime \prime$ & 27 & "I & $4 \mathrm{~m} \times 18 \mathrm{~m}$ \\
\hline 7 & ロータリーキルン & $4 \prime \prime$ & 27 & " & $3.6 \mathrm{~m} \phi \times 71 \mathrm{~m}$ \\
\hline 8 & ダストシックナ & $1 " \prime$ & 800 & $\mathrm{~m}^{3} / \mathrm{h}$ & $20 \mathrm{~m} \phi$ \\
\hline 9 & 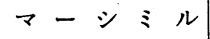 & $5 \prime \prime$ & 25 & Dry $-\mathrm{t} / \mathrm{h}$ ·基 & $2.4 \mathrm{~m} \phi \times 1.8 \mathrm{~m}$ \\
\hline 10 & ジ & $13 "$ & 15 & "I & \\
\hline 11 & 磁＼cjkstart選 & $18 \prime \prime$ & 15 & " & \\
\hline 12 & 分 級 機 & $1 " \prime$ & 300 & $\mathrm{~m}^{3} / \mathrm{h}$ & $1.5 \mathrm{~m} \phi \times 10 \mathrm{~m}$ \\
\hline 13 & 排水 シックナ & $1 " \prime$ & 3,000 & " & $32 \mathrm{~m} \phi$ \\
\hline 14 & " & $1 " \prime$ & 600 & " & $20 \mathrm{~m} \phi$ \\
\hline
\end{tabular}

第 2 表 主要設備仕様

第3表 鉣 石 組 成

\begin{tabular}{l|r|c|c|c|c|c|c}
\hline \multicolumn{1}{c|}{ 産 地 } & $\mathrm{Igloss}$ & $\mathrm{Si} \mathrm{O}_{2}$ & $\mathrm{Fe}$ & $\mathrm{Al}_{2} \mathrm{O}_{3}$ & $\mathrm{Ni}$ & $\mathrm{MgO}$ & 水分 \\
\hline PORO & 9.75 & 40.72 & 12.02 & 0.80 & 2.50 & 26.44 & 23.7 \\
NAKETY & 10.40 & 42.00 & 12.53 & 0.97 & 2.47 & 24.15 & 26.1 \\
POMALAA & 8.74 & 46.01 & 12.06 & 2.14 & 2.35 & 21.02 & 28.9 \\
RIO TUBA & 11.08 & 40.59 & 15.05 & 1.04 & 2.32 & 21.38 & 28.9 \\
\hline
\end{tabular}

第 4 表 無煙炭, コークス組成

\begin{tabular}{c|cccccccc}
\hline & T.M & I.M & Ash & V.M & FC & P & S & $\begin{array}{c}\text { kcal } \\
/ \mathrm{kg}\end{array}$ \\
\hline $\begin{array}{c}\text { 無 煙炭 } \\
(\text { 山西 })\end{array}$ & - & 4.0 & 12.3 & 6.4 & 77.4 & 0.004 & 0.14 & 6,240 \\
$\begin{array}{c}\text { ユークス } \\
(\text { 君津 ) }\end{array}$ & 26.2 & - & 12.0 & 3.2 & 84.9 & 0.044 & 0.50 & 6,920 \\
\hline
\end{tabular}

粉砕された原料は約 $50 \%$ の水分を含んだスラリーであり,タン クに貯鉱し, 無煙炭, 石灰石の調合を行なう。調合スラリーは濃 度変動防止用の払出装置 (タンク) を経てポンプで脱水工程に送 られる。

脱水工程では高分子凝集剂を約 $0.2 \mathrm{~kg} /$ 原料ー $\mathrm{t}$ 添加してドラ ムフィルタに給鉱し, 水分 $32 \%$ ケケークとなる。

ケークはダスト類と混鍊され, 成型機で約 $12 \mathrm{~mm} \phi$ の団鉱とな 
第 5 表 スラグ組 成

\begin{tabular}{c|c|c|c|c|c|c}
\hline $\mathrm{C}$ & $\mathrm{SiO}_{2}$ & $\mathrm{~T} . \mathrm{Fe}$ & $\mathrm{Al}_{2} \mathrm{O}_{3}$ & $\mathrm{MgO}$ & $\mathrm{CaO}$ & $\mathrm{Ni}^{++}$ \\
\hline 0.2 & 53.4 & 6.0 & 2.5 & 28.4 & 5.7 & 0.1 \\
\hline
\end{tabular}

第 6 表 ルッペ組成

\begin{tabular}{c|c|c|c|c|c|r}
\hline $\mathrm{Ni}$ & $\mathrm{C}$ & $\mathrm{P}$ & $\mathrm{S}$ & $\mathrm{Cr}$ & $\mathrm{S} \mathrm{i}$ & 混入スラグ \\
\hline $18 \sim 22$ & $<0.1$ & $<0.03$ & $0.1 \sim 0.4$ & $<0.5$ & $<0.1$ & $<2.0$ \\
\hline
\end{tabular}

つて予熱グレートに装入される。予熱グレートでは原料層厚を約 $180 \mathrm{~mm}$ 前後に自動的にコントロールし, 約 $700^{\circ} \mathrm{C}$ のキルン排ガ スによつて水分 $10 \%$ まで乾燥し，キルンに装入する。

\section{$3 \cdot 4$ 還元, メタルの造粒}

ロータリーキルン内では, 乾燥 $\rightarrow$ 予熱 $\rightarrow$ 還元 $\rightarrow$ 造涬 $\rightarrow$ タル造 粒といつた反応が連続的に進行する。このためのエネルギーは原 料中に配合された無煙炭とキルン排出端から吹き込む重油である。 鉱石装入量は $380 \mathrm{dry} \mathrm{t} /$ 日炬で, 炭材原単位は $140 \mathrm{~kg} / \mathrm{dry}-$ ore $\mathrm{t}$, 重油原単位は $60 \mathrm{l} / \mathrm{dry}$ ore $\mathrm{t}$ であり, 燃焼用空気はブ ロワーでの押込みと排風機で誘引される空気である。炬体は 40 50 R/Hで回転される。排出端より15２0m附近より Slagfor mation が始まるが，いわゆる， semifused 状態のまま反応が進 行するように温度のコントロールを行なう。コントロール要因と しては空気量と重油量で, 空気量は排風機の回転数によつてュン トロールする。 semifused 状態の中で還元も急激に進行し, メタ ルの造粒も盛んとなるが, メタルの造粒を界面反応的にみると表 面張力に影響を及ぼす $\mathrm{S}$ や，スラグの粘性に影響する $\mathrm{Fe} \mathrm{O}$, $\mathrm{Al}_{2} \mathrm{O}_{3}$ 等の存在が造粒及びスラグとの分離に効果がある。

焼成されたクリンカは鉱物学的にはェンスタタイトを主成分と し, $50 \sim 100 \mathrm{~mm}$ の塊状で, 中に粒状のメタル (ルッペ)が混在 している。キルンより排出されたクリンカは $1,300^{\circ} \mathrm{C}$ の semifused 状態にあるが, 水䂶溝に落ち, 急冷されて選別工程に送られ る。第 3 図にキルンの物量収支を, 第 5 表にスラグの組成例を示 す。

\section{$3 \cdot 5$ 選 別}

水冷されたクリンカはマーシミルで粉砕され, メタルとスラグ に単体分離され, つづいて $1.2 \mathrm{~mm}$ の振動ふるいで 2 種類に分けら れる。選別はメタル（比重：7.8) とスラグ(比重：3.0)の比 重差を利用して, 粒度に対応して当社で改良を重ねた $\mathrm{Jig}$ によ つて行なわれ，粒状×タル（ルッペ）が回収される。

$\mathrm{J}$ i g の尾鉱は永久磁石型の磁力選鉱機にかけられ，その精鉱 は再び微粒用に開発したアンダ回収型の Jigにかけられ, その 精鉱は製品とし, 尾鉱は片刃としてキルンに還流される。回収さ れたルッペは製品として専用コンテナに積み, $\mathrm{Ni}$ 他成分を確定 し, 貨車で発送される。

市販用ルッべは原料, 燃料を変えて製鍊し， $20 \mathrm{~kg}$ 袋詰めで発 送される。第 6 表にルッペの組成例を示す。

磁選機の尾鉱はスラグ処理設備ヘポンプで輸送され，再資源化 に供される。

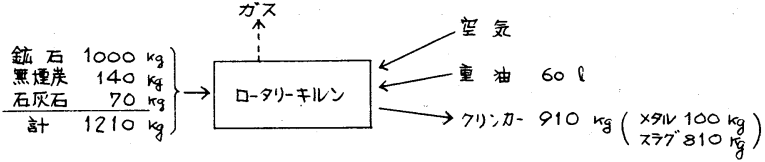

第 3図キルンの物量収支概略値

第 7 表 粗粒スラグの諸性質

(1) 分析値 第 5 表のスラグ組成にほぼ同じ。

(2) 比重, 吸水量, 単位容積質量

\begin{tabular}{ll}
\hline 表 乾 比重 & 3.08 \\
絶 乾 比重 & 3.06 \\
吸 水量 & $0.65 \%$ \\
単位容積質量 & $1.83 \mathrm{t} / \mathrm{m}^{3}$
\end{tabular}

(3) 粒度分布

\begin{tabular}{lr|rrrrr}
\hline ふるい目 $(\mathrm{mm})$ & 2.5 & 1.2 & 0.6 & 0.3 & 1.5 \\
\hline ふるい通過率 $(\%)$ & 100 & 93 & 66 & 38 & 16 \\
\hline
\end{tabular}

(4) 硬さ

板ガラス（モース硬度 5.5 ) より硬く, 石英（モース硬度 7 )に近い。

\section{$3 \cdot 6$ スラグ処理}

スラグは分級機で粗粒と徽粒に分けられ，粗粒は市販され，コ ンクリート細骨材，アスファルト混和剤として利用されており， 天然細砂が枯渴し, 骨材事情が悪化しつつある今, 粒度調整材と してはもとより, 最近では地盤改良材としての利用も払大してい る。第 7 表に諸性質を示す。

昭和 38 年に生産を開始したコンクリートブロックは現在月産 $500 \sim 1,000 \mathrm{t}$ である。

微粒については水切り後, 埋立材として使用している。

\section{4. 結}

当社のプロセスは使用電力が少ない点でコストメリットを保つ ているが, 選別工程を有し, $\mathrm{Ni}$ 回收率は残念ながらエルケム法 に及ばない。製品は AOD 製鋼の冷材として有効である反面, ス ラグを含み，かつ， $\mathrm{S}$ 含有率が高いという久点をもつている。

当社はこのような実態をふまえて, 省エネルギー, $\mathrm{Ni}$ 収率向 上, 製品品質の向上のプロジュクトを推進している。現在実施し ているプロジェクト完成時には, $\mathrm{Ni}$ 収率, 製品品質とも大幅に 改善できるものと考えている。また，エネルギー供給源の多様化 と原価低減をめざして, 石炭燃料への転換も昭和 56 年, 完成予定 である。

さらに，今後は省エネルギー対策として熱回収や原料処理方式 の再検討を, 生産効率向上対策として操炉法の改良と管理方式の 整備をすすめる一方, スラグ再資源化の研究も推進し, 将来的に は, 現地製鍊も志向して, 基礎研究, プロセス解析を推進し, 輸 出できるプロセスとしてのNippon Yakin-Oheyama Process の確立に努める所存である。

Ferro-Nickel Smelting at Oheyama Nickel Co., Ltd.

by Haruo ARAI

This company was founded in 1942 as Oheyama Plant of Nippon Yakin Kogyo Co., Ltd. to produce ferro-nickel from low grade nickel oxide ores of Mt. Oheyama. The smelting method at that time was something like the one known as the Krupp-Renn process, and operation continued till the end of World War II. 
The plant began to run again in 1952, switching to imported ores from New Caledonia for its raw materials. The Krupp-Renn process, which we employed for treatment of nickel ores, has been modified and developed remarkably since then. Our engineering experiences and techniques stored over many years enabled us to achieve technical innovation and reformation in whole process, such as grinding and homogenization of materials, filtration, pelletizing, preheating, kilnoperation and jigging. We have now established a unique process for Fe-Ni smelting, which might be named "Nippon Yakin -
Oheyama Process".

In 1975 Oheyama Nickel Co. separated from Nippon Yakin Kogyo Co. Now monthly nickel production amounts to some 900 tons, and almost all of the products is sold to Nippon Yakin Kogyo Co. for stainless steel production.

Nippon Yakin - Oheyama Process has drawn attention to its low production cost, which is due essentially to its low consumption of expensive electricity and motive power use. The oxide ores within the rotary kiln are roasted and reduced by both fuel oil and coal. In the partially fused slag, the reduced metal particles then coalesce and grow to size of 0.5 to $30 \mathrm{~mm}$, which is called "Luppe". Chemical analysis in percent ; $\mathrm{C}<0.1, \mathrm{Si}<0.1, \mathrm{Ni} 18-22$, slag $<2$. steel making.

Owing to its properties "Luppe" is also useful as coolant source for AOD process which is most important in stainless

\section{〔3-15] 日本鉱業佐賀関製錬所におけるフェロニッケル製鍊}

$$
\begin{aligned}
& \text { 沼 莞 爾 }{ }^{1} \text { 坂 本和 } \text { 平 }^{2} \\
& \text { 森田 正 } \text { 夫 }^{3} \text { 田中克 } \text { 芳 }^{4}
\end{aligned}
$$

\section{1. 緒言}

昭和 8 年, 佐賀関製鍊所において, 業界初の直接還元溶解法に よるフェロニッケルの生産を開始した。当時は月間処理鉱石量は

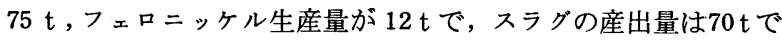
あつた。これが今日では, 鉱石量が月間約 $50,000 \mathrm{t}$, 生産量は, フェロニッケル $5,000 \mathrm{t}$ そして, スラグは 40,000 t となり, 生産 量は実に 400 倍もの規模に及んでいる。昭和18年から昭和 26 年ま での 8 年間は, 諸般の事情により生産を中断したものの, 今日ま での 47 年間には, フェロニッケルの特殊鋼製造への活用, 溶釷炉 法の開発と発展, スラグの珪カル肥料への利用, 酸化精製法の導 入等を始め, クルップレン法, エルケム式電気炉法の採用を含め, 実に多彩な技術的变遷を行なつてきた ${ }^{a ｝ \text { 。特に昭和 } 40 \text { 年代は規模， }$ 技術両面での大躍進時代であつた。フェロニッケル鋳造方法の変 更, ロータリーキルンによるクルップレン法の実施, 高温熱風炉 の採用, 大型溶鉱炉の建設, L D 転炬法の採用, そして大型電気 师の建設等を行ない，大幅な省力化，省エネルギー化と合せて， 当社フェロニッケル事業の現態勢を築き上げた時代でもあつた。

現在は，電気炉法と日鉱独自の溶鉱炉法との二方式により，そ れぞれの長所特質を生かし, 原料とェネルギー両面での有利さを 発揮しつつ, 月間凡そ $1,200 \mathrm{t}$ のフェロニッケル生産を順調に続 けている。

\section{2. 経緯}

最近 10 年間の推移を第 1 表に示す。

第 1 表 最近 10 年の推移

昭和 42 年10月 クルップレン法によるフェロニッケルルッペ の製造開始。

昭和 44年 6 月 No. 4 溶鉱炉吹入れ

LD 転炬操業開始

昭和 46 年 3 月 大型電気炉通電開始

昭和 47 年 3 月 溶銑運搬車稼動

昭和 51 年 9 月 No. 4 溶鉱炉一部改修

昭和53年 7 月 キルンへの予備還元装置設置

昭和55年 2 月 溶鉱炉送風除湿装置設置

1. 正会員 日本鉱業株式会社佐賀関製鍊所製鍊部副部長

2. 正会員 日本鉱業株式会社佐賀関製錸所製鍊部ニッケル課

3. 正会員 日本釷業株式会社ニッケル事業部技術部技師長

4. 正会員 日本鉱業株式会社ニッケル事業部技術部長
昭和 44 年には, 従来の 2 倍の能力を持つ, 世界唯一のフェロ= ッケル製鍊用大型溶鉱炉を稼動させ，同時に，精製工程において も, 高生産性で確実度・安全性の高いL D 転炬による純酸素上吹 操業を開始した。これに引き続き, 昭和 46 年には, これも当時最 大級の容量 $27,000 \mathrm{kVA}$ の電気炉を採用した。

昭和 42 年から操業を続けてきたロータリーキルンによるクルッ プレン法の技術と技能は，そのままこの電気灯法に引き継いでゆ

\begin{tabular}{|c|c|}
\hline 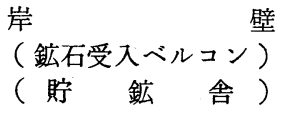 & $\begin{array}{l}30,000 \mathrm{t} \text { 岸壁 } \\
1,300 \mathrm{t} / \mathrm{hr} \\
120,000 \mathrm{t}\end{array}$ \\
\hline $\begin{array}{l}\text { ロータリードライヤ } \\
\text { 団 } \\
\text { 鉱 }\end{array}$ & $\begin{array}{l}60 \mathrm{t} / \mathrm{hr} \times 3 \text { 基 } \\
30 \mathrm{t} / \mathrm{hr} \times 3 \text { 基 } \\
30 \mathrm{t} / \mathrm{hr} \times 2 \text { 基 } \\
3.5 \mathrm{~m} \phi \times 80 \mathrm{~mL} \times 2 \text { 基 }\end{array}$ \\
\hline $\begin{array}{lll}\text { 溶 } & \text { 鉱 } & \text { 炬 } \\
\text { 熱 } & \text { 風 } & \text { 炬 } \\
\text { 電 } & \text { 気 } & \text { 炬 }\end{array}$ & $\begin{array}{l}100 \mathrm{~m}^{3} \times 1 \text { 基, ダブルベル方式 } \\
1050^{\circ} \mathrm{C}, 1 \text { 式 } \\
27,000 \mathrm{kVA} \times 1 \text { 基 }\end{array}$ \\
\hline 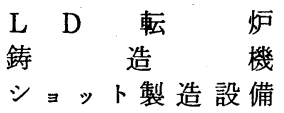 & $\begin{array}{l}13 \mathrm{t} / \mathrm{ch} \times 2 \text { 基, 移動台車方式 } \\
25 \mathrm{t} / \mathrm{ch} \times 1 \text { 基, } 15 \mathrm{t} / \mathrm{ch} \times 2 \text { 基 } \\
15 \mathrm{t} / \mathrm{ch} \times 1 \text { 式 }\end{array}$ \\
\hline
\end{tabular}

第 2 表 主要設備仕様

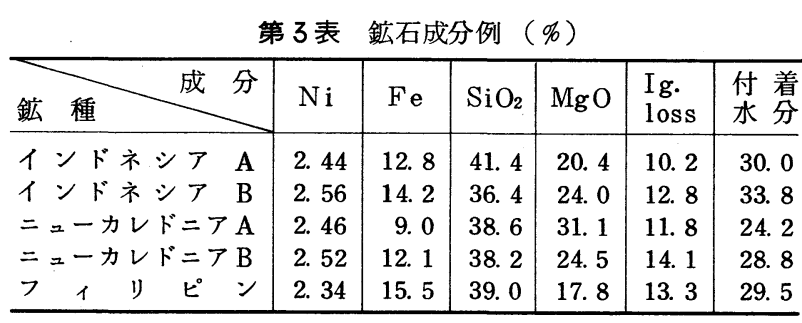

第 4 表 クルードフェロニッケル成分例（\%)

\begin{tabular}{c|c|c|c|c|c|c|c}
\hline & $\mathrm{Ni}$ & $\mathrm{C}$ & $\mathrm{Si}$ & $\mathrm{Cr}$ & $\mathrm{S}$ & $\mathrm{P}$ & $\mathrm{Fe}$ \\
\hline 溶鉱炉出 & 17.4 & 2.6 & 3.9 & 2.1 & 0.60 & 0.15 & $\mathrm{Ba} 1$. \\
電気炉出 & 19.8 & 2.2 & 2.8 & 1.6 & 0.32 & 0.012 & $\mathrm{Ba} 1$. \\
\hline
\end{tabular}

a）昭和 43 年までの詳練は, 前回の非鉄製鍊号日本鉱業会誌Vo 1.84, №.963(1968) を参照されたい。 